\title{
Model Dakwah Hizbiyah
}

\author{
Ismawati $^{{ }^{*}}$, RS Syamsuddin ${ }^{2}$, Nase $^{1}$ \\ ${ }^{1}$ Jurusan Komunikasi dan Penyiaran Islam, Fakultas Dakwah dan Komunikasi, UIN Sunan \\ Gunung Djati, Bandung \\ ${ }^{2}$ Jurusan Pengembangan Masyarakat Islam, Fakultas Dakwah dan Komunikasi, UIN Sunan \\ Gunung Djati, Bandung \\ *Email : ismamativ@gmail.com
}

\begin{abstract}
ABSTRAK
Penelitian ini bertujuan untuk mengetahui model dakwah di Pimpinan Cabang Pemudi Persatuan Islam Margaasih. Perihal kegiatan dakwah di Pimpinan Cabang Pemudi Persatuan Islam meliputi materi dakwah serta metode yang digunakan dalam menyampaikan pesan dakwah kemudian efek dari penerapan dari materi dakwah kepada anggota pemudi. Metode pada penelitian ini menggunakan metode deskriptif. Pengumpulan data peneliti menggunakan teknik observasi, wawancara dan dokumentasi. Analisis data dalam penelitian ini digunakan penafsiran logika yang dilakukan dengan kontek komunikasi dan penyiaran Islam.

Hasil penelitian ini menunjukan bahwa model dakwah Pimpinan Cabang Pemudi Persatuan Islam Margaasih adanya proses dakwah yang para mubaligh menyampaikan pesan dakwah kepada mad'u mempersiapakan penyampaian yang dapat direspon dengan baik. Model dakwah menjadi alat dan ciri khas tersendiri ketika dalam menyampaikan. Didalam konsep kajian dakwah menanamkan keilmuan yang berlandaskan dengan Al-Qur'an dan As-Sunnah.
\end{abstract}

Kata Kunci : Model Dakwah, Hizbiyah

\section{ABSTRACT}

This study aims to determine the model of da'wah in the Islamic Youth Branch Manager of Margaasih. Regarding the da'wah activities in the Branch Leader of the Islamic Unity Youth, including da'wah material as well as the methods used in delivering da'wah messages, then the effects of the application of da'wah material to young female members. The method in this study uses descriptive methods. Data collection researchers used observation, interview and documentation techniques. Analysis of the data in this study used logical interpretations conducted with the context of Islamic communication and broadcasting. 
The results of this study indicate that the model of the Branch Leader of the Youth of Islamic Unity Margaasib preaching process that the preachers conveyed the message of da'wah to mad'u preparing the delivery that could be responded well. Da'wah models become their own tools and characteristics when conveying. In the concept of da'wah studies instill knowledge that is based on the Qur'an and the Sunnah.

Keywords: Model Da'wah, Hizbiyah

\section{PENDAHULUAN}

Perkembangan gerakan ke-Islaman di Indonesia sangat mempengaruhi suatu perubahan, yakni dalam bidang sosial, ekonomi, politik hingga kebudayaan yang menyangkut perubahan antar kelompok maupun individu serta perubahan sikap dan perilaku. Islam sebagai sebuah agama terbesar di Indonesia, juga menjadi sebuah agama yang mayoritas yang dianut oleh masyarakat.

Oleh karena itu menunjukan keberadaan Islam di akui untuk menyampaikan jalan dakwah yang tidak selamanya mudah diterima oleh masyarakat karena banyak pemikiran dan pemahaman yang berbeda dalam menyampaikan sebuah risalah dari Rasulullah SAW. Kemunculan organisasiorganisasi ke-Islaman di Indonesia merupakan representasi dari kesadaran ulama terdahulu dalam menyikapi pemikiran sesuai dengan kondisi masyarakat atau umat pada saat itu. Diantara organisasi ke-Islaman terbesar di Indonesia yaitu, Sarekat Islam, Muhammadiyah, Persatuan Islam dan Nahdhatul Ulama. Organisasi-organisasi gerakan tersebut bertujuan sama yaitu untuk berdakwah untuk menyebarluaskan ajaran Islam sesuai dengan Al-Qur'an dan as-Sunnah.

Pada realisasinya, melaksanakan kewajiban berdakwah harus dilihat juga dari interaksi da'i dengan mad'u-nya. ada beberapa tingkatan dakwah yang bisa menjadi acuan untuk menyampaikan pesan dakwah kepada mad'u. Terlebih jikalau dakwah kepada mad'u yang banyak. Seperti tingkatan dakwah hizbiyah, dakwah bizbiyah atau jama'ah adalah proses dakwah yang dilakukan oleh da'i yang mengidentifikasikan dirinya dengan artibut suatu lembaga atau organisasi dakwah tertentu, kemudian mendakwahi anggotanya atau orang lain diluar anggota suatu organisasi tersebut. (Enjang, et al., 2009: 68).

Banyak lembaga dakwah yang menjadi jembatan dalam menyampaikan pesan dakwah. Diantaranya yang termasuk dakwah hizbiyah di organisasi keislaman ialah NU, Muhammadiyah, Persatuan Islam dan lain-lainnya. Dakwah hizbiyah adalah salah satu model dakwah organisasi di Pimpinan Pusat Persatuan Islam dalam segala aspek kegiatan berdakwah. Persatuan Islam adalah salah satu organisasi kejam'iyyah di Indonesia yang mengemban misi untuk menegakan AlQur'an dan As-Sunnah. Keunggulan dalam berdakwah di lembaga Persatuan Islam menerapkan ruhul jihad dalam berdakwah dengan bersumber Al-qur'an dan As-Sunnah menjadi pedoman dengan keciri khas-annya dalam menyebarkan 
Ismawati, Syamsuddin SR \& Nase

dakwah. Salah satunya dengan mengirim para da’i yang ahli dalam memyampaikan dakwah ke belahan timur dari luar jawa. Didalam organisasi kejam'iyyahan ada beberapa bagian Persatuan Islam. Salah satunya ada bagian Pemudi Persatuan Islam.

Penelitian ini menjelaskan penelitian yang memiliki kemiripan atau serupa dengan penelitian tedahulu, pertama A, Rojib pada tahun 2015 degan judul "Model Dakwah Ikatan Remaja Attaqwa (IKRA) terhadap Remaja (Penelitian Di Rt 002 Rw 08 Kelurahan Bahagia Kecamata Babelan Kabupaen Bekasi). Pada penelitian ini menggunakan pendekatan kualitatif dan menggunakan analisis data deskriptif. Model dakwah yang digunakan oleh Ikatan Remaja Attadwa (IKRA) terhadap remaja mempunyai beberapa model itu menjadi jembatan dalam menyampaikan dakwah serta aktifitas dakwah yang berhubungan dengan permasalah dimasyarakat. Persamaanya ialah sama-sama meneliti mengenai model dakwah. Perbedaanya penelitian yang dilakukan oleh A. Rojabi membahas mengenai model dakwah dalam sebuah komunitas.

Yang Kedua, penelitian skripsi Model Tabligh KH. Ahmad Sarkosi Subki dalam Pembinaan Keagamaan Masyarakat pada tahun 2013 dandalam penelitiannya mengguakan pendekatan kualitatif dengan analisis deskriftif. Dalam penelitian yang dilakukan oleh Mariyatul Kibtiyah objek pembahasannya adalah model tabligh seorang ustadz (da'i), sedangkan yang peneliti teliti pada penelitian ini objeknya adalah suatu model dakwah (organisasi).

Yang ketiga, penelitian skripsi Model Dakwah Pada Komunitas Teras Dakwah (Studi Deskriptif Model Dakwah pada Komunitas Dakwah di Kampung Nitikan,Sororutan, Umbulharjo, Yogyakarta) oleh Eko Purwanto yang memiliki kesimpulan bahwa jenis dakwah yang digunakan oleh komunitas Teras Dakwah adalah dakwah kultural. Persamaanya adalah sama-sama membahas tentang sebuah model. Perbedaanya adalah penelitian yangdilakukan oleh Eko membahas tentang modek dakwah komunitas sedangkan peneliti teliti membahas tentang model dakwah. Ada beberapa penelitian yang sudah dilakukan terkait studi deskriptif tentang kegiatan dakwah di Pimpinan Cabang Pemudi Persatuan Islam Margaasih dinggap relevan. Penelitian ini dilakukan di Jalan Mahmud Kampung Curug No. 271. Rt 003 Rw 008 Desa Rahayu Kecamatan Margaasih Kabupaten Bandung.

Berdasarkan latar belakang penelitian yang telah dikemukakan maka yang menjadi fokus penelitian dalam penelitian ini, diantaranya Pertama, Bagaimana konsep kajian dakwah hizbiyah di Pimpinan Cabang Pemudi Persatuan Islam Margaasih? Kedua, Materi Apa yang sampaikan dalam kegiatan dakwah di Pimpinan Cabang Pemudi Persatuan Islam Margaasih? Ketiga, Bagaimana metode dakwah di Pimpinan Cabang Pemudi Persatuan Islam Margaasih ?.

Metode penelitian yang digunakan dalam penelitian ini adalah metode deskriptif yaitu suatu penelitian kualitatif dengan menggambarkan 
(mendeskripsikan) populasi yang diteliti. Jenis penelitian deskripsif bertujuan membuat deskpsi secara sistematis, faktual, dan akurat tentang fakta-fakta dan sifat-sifat populasi atau objek tertentu. Dengan demikian, pada penelitian ini peneliti menggambarkan atau mendeskripsikan kegiatan dakwah di Pimpinan Cabang Pemudi Persatuan Margaasih. Kemudian hasil data dikumpulkan, diolah dan dianalisis untuk kemudian dilaporkan dalam Bab III.

Pemudi Persatuan Islam menjadi wadah menyebarkan pesan dakwah melalui kegiatan-kegiatan dakwah bertujuan sebagai pengemban dan pelanjut misi Persatuan Islam, Pemudi Persis harus tampil menjadi generasi yang bersibghah kepada Al-Qur'an dan As-Sunnah. Memiliki ruh jihad dan ruh ijtihad yang tinggi, berilmu, serta berakhlaqul karimah. Sehingga pemikiran dan tindakan pemudi diharapkan dapat mewujudkan bunyanul Islam. Karena diketahui bahwa lembaga organisasi keislaman Persis memiliki bagian tersendiri. Seperti, Persis, Persistri, Pemuda, Pemudi, Ikatan pelajar Persis dan keorganisasian sekolah yang dinamakan Rijalul ghad dan Ummahatul Ghad.

Setiap bagian Persis memiliki kegiatan dakwah tersendiri. Seperti halnya Pemudi Persis mempunyai kegiatan dakwah yang mengharuskan kaum muslimah Persis taat akan perintah Allah SWT Sesuai dengan Al-qur'an dan asSunnah. Ketertarikan peneliti untuk meneliti kegiatan dakwah Pemudi Persis karena banyak sekali kegiatan dakwah yang menarik peneliti untuk diteliti. Organisasi Persis khususnya Pemudi Persis tentu mempunyai perbedaan dan kesamaan dengan organisasi keislaman lainnya dengan berbagai sudut pandang. Didalam keorganisasian Pemudi Persis terdapat pembagian dari setiap wilayah di Indoensia. Pimpinan Pusat Pemudi Persis menjadi acuan dan kebijakan serta kewenangan sebagai kedudukan paling tinggi. Tidak hanya itu, di wilayah, daerah serta ke anggotaan yang lebih termengerucut seperti cabang/kecamatan dan jama'ah keorganisasian Pemudi Persis dapat terkontrol serta memudahkan untuk menyampaikan pesan dakwah. Dalam penelitian ini peneliti akan meneliti setiap kegiatan dakwah yang ada di cabang khususnya cabang Margaasih Kabupaten Bandung. Karena ada beberapa kegiatan dakwah yang menarik sehingga peneliti tertarik untuk diteliti.

\section{LANDASAN TEORITIS}

\section{Penjelasan Model}

Model merupakan representasi yang dituangkan dalam kata-kata atau gambar dari serangkaian proses atau sistem. Sehingga dapat menjelaskan rangakai proses tersebut dengan rinci dan jelas. Adanya segala proses dari pembuatan model tersebut tidak dapat lepas antara proses satu dengan proses yang lainnya. Sehingga, proses yang terjadi atau yang terjalin bersifat pararel menjelaskan hubungan yang berkesinambuangan (Abdul, 2013 : 16). 
Model tidak dapat diartikan teori, karena pembentukan model bisa saja berubah sesuai dengan penelitian yang objektif. Untuk itu, model tidak bisa diartikan sebagai teori. Namun setiap teori sudah pasti menganudung model karena teori sudah teruji dari segala aspek dan pengakuannya (Abdul, 2013 : 17).

Secara struktural, model dapat dikenal dengan sebutan model ikonis atau model yang menyimpan karkterikstik fisik dari hal yang digambarkan, seperti maket bangunan; model analogis atau model yang membandingkan atau menyamakan hal-hal yang digambarkan dengan hal lain yang hampir mirip dengan hal-hal tersebut. Seperti halnya gambaran sistem informasi komuputer untuk mengambanrkan proses berpikir manusia; model simbolis tau model yang menggambarkan lambang-lambang yang melukiskan yang ada didunia nyata, seperti "KK+GP+SS=E adanya kredibilitas komunikator, gaya penyusunan pesan dari situasi sasaran komunikan dapat melahirkan efek komunikasi" (Kustandi, 2013 : 136).

\section{Penjelasan Tentang Dakwah Hizbiyah}

Dakwah Secara etimologi, kata dakwah berasal dari bahasa Arab dalam bentuk masdhar dari kata دَعَا ـ يَذْعُوْ secara harfiah berarti artinya panggilan, seruan, do'a, ajakan, undangan dan propaganda (Subandi, 1994:10). Pengertian dakwah dari segi bahasa ini memiliki karakteristik yang umum, karena mengajak, memanggil menyeru bisa terjadi kepada kebaikan atau keburukan. Dalam konteks pengertian bahasa dalam Al-Qur'an penggunaan kata dakwah digunakan untuk mengajak kepada kebaikan dan mengajak kepada keburukan juga penggunaan kata dakwah bisa berarti do'a.

Sebagimana Firman Allah SWT dalam QS. Al-Baraqah ayat 186 :

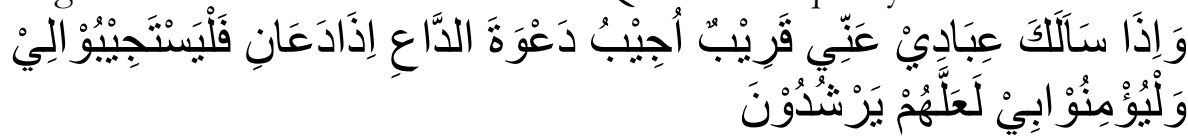

"Dan apabila hamba-hamba-Ku bertanya kepada (Muhammad) tentang

Aku, maka sesungguhnya Aku dekat. Aku Kabulkan permohonan orang yang berdoa apabbila dia berdoa kepada-Ku. Hendaklah mereka itu memenuhi (perintah)-Ku dan beriman kepada-Ku, agar mereka memperoleh kebenaran" (Departemen Agama, 2004: 28).

Karena dakwah dapat menunjukan sebagai do'a seseorang atau permohonan yang sangat mendesak yang ditujukan kehadirat Allag SWT. Maka, mengutamakan bahwa dakwah adalah hal individual yang dilakukan anatar da'i dan mad'u serta melibatkan Sang Pencipta.

Secara istilah (terminologi), pengertian dakwah meliputi ajakan, keteladanan, dan tindakan konkret untuk melakukan tindakan yang baik bagi keselamatan dunia dan akhhirat. Sebagaimana makna dakwah mengambil pada ayat al-Qur'an dalam surat An-Nahl ayat 125. 


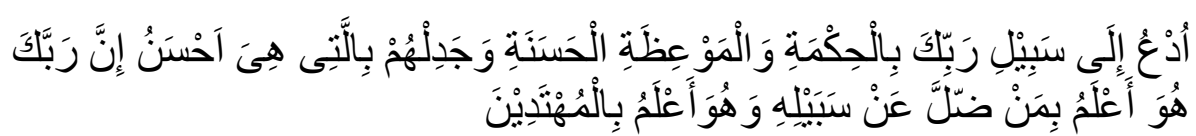

"Serulah (manusia) kepada jalan Tuhan-Mu dengan hikmah dan pelajaran yang baik dan bantahlah mereka dengan cara yang baik. Sesungguhnya Tuhanmu Dialah yang lebih mengetahui tentang siapa yang tersesat dari jalan-Nya dan Dialah yang lebih mengetahui orang-orang yang mendapat petunjuk." (Departemen Agama, 2004: 281).

Dari ayat diatas menerangkan bahwa kewajiban kita sebagai hamba Allah senantiasa untuk menyeru, mengajak kepada orang lain untuk berbuat kebaikan dan selalu beribadah kepada Allah SWT.

Unsur-unsur dakwahnya Terdapat enam unsur pokok (utama) dalam proses dakwah yaitu: da'i, mad'u, maudu' (materi dakwah) yang sering disebut pesan dakwah, ushlub (metode dakwah), washilah (media dakwah), dan tujuan dakwah. Sedangkan konteks dakwah dan respons balik (feed back) merupakan situasi dan implikasi yang tak terpisahkan ketika terjadi proses dakwah dalam arti unsur yang melekat. Dibawah ini akan dijelaskan megenai unsur-unsur dakwah, Da'i adalah orang yang aktif melaksanakan dakwah kepada masyarakat. Kedua, Mad'u adalah isim maful (objek penderita) dari kata da'a - yad'u. Adapun artinya dalam istilah adalah orang yang disampaikan kepadanya dakwah (orang yang didakwahi). Mad'u ini mungkin juga diartikan "manusia secara mutlak, dekat atau jauh, muslim atau nonmuslim, laki-laki atau perempuan, dan sebagainya (al-Bayanuny, 2001: 37).

Adapun maudu' nya Maudu' atau materi dakwah adalah pesan-pesan, materi atau segala sesuatu yang harus disampikan oleh da'i kepada mad'u, yaitu keseluruhan ajaran Islam, yang ada didalam Kitabullah dan Sunnah Rasul-Nya. Dan ushlub atau metode adalah cara atau jalam yang harus dilalui untuk mencapai suatu tujuan (Enjang dan Aliyudin, 2009: 68-69). Sumber lain menyebutkan bahwa metode adalah acara atau jalan yang harus dilalui untuk mencapai suatu tujuan. Sedangkan wasilah merupakan bahasa Arab yang berarti: aal-wushlah. Al-Ittishal, yaitu segala hal yang dapat menghantarkan tercapainya sesuatu yang diinginkan (al-Bayanuni, 2001: 48).

Sedangkan pengertian Hizbiyah secara bahasa dalam kitab Lisaanul Arab yakni : "Al-bizb" artinya sekelompok manusia, jamaknya: ahzab (Yulian, 2018). Adapun Hizbiyah menurut Al-qur'an Surat Al-Mu'minun ayat 53 berartikan al fariq; al firqah, artinya kelompok agama; sekte; aliran.

Menurut Syukriadi Sambas bahwasanya dakwah yang dilakukan oleh kelompok menurut tobaqot atau tingkatannya dinamakan dakwah fiiah qalilah (kelompok kecil), adanya proses dakwah yang dilakukan oleh da'i kepada madu yang berjumlah lima hingga dua puluh orang. Sedangkan dakwah fiah katsirah (kelompok banyak); proses dakwah yang dilakukan oleh da'i kepada mad'u yang 
Ismawati, Syamsuddin SR \& Nase

berjumlah dari dua puluh orang hingga tak terbatas. Selain itu, dakwah kelompok dapat dikategorikan sebagai dakwah yang terorganisir dan dakwah yang tidak terorganisir. Adapun dakwah yang terorganisir disebut dengan dakwah bizbiyah.

Dakwah bizbiyah juga merupakan dakwah jamaah yang dilakukan oleh kelompok-kelompok yang mengatasnamakan lembaga itu sendiri. Dikaitkan dengan Model Komunikasi dakwah umumi yaitu dakwah yang disampaikan kepada masyarakat umum yang memiliki latar belakang berbeda-beda, berbeda karena status sosial, profesi pendidikan, etnis, usia dan sebagainya. Model dakwah ini sesungguhnya lebih heterogen karena sasaran dakwahnya heterogen. Heterogenitas sasaran dakwah sangat alamiah, dan dakwah berlaku secara universal. Dalam kontes ini, Ismail Al-Faruqi dan Lamya Al-Faruqi (2001:221) mengungkapkan: Semua manusia merupakan objek dakwah Islam. Eksistensi, transendensi, dan keeasaan Allah, relevansi-Nya dengan dunia dan kehidupan ini, perintah-Nya, menjadi perhatian setiap orang. Tak ada orang yang dikecualikan dari debat mengenai masalah agama. Allah menyeru semua manusia kepada-Nya dan Dialah pencipta dan Tuhan mereka. Membatasi seruan-Nya berarti juga membatasi Diri-Nya dan kuasa-Nya, atau berarti kesewenangan yang bertentangan dengan keadilan-Nya (Saepuloh, Ujang 2009: 682)

\section{Komunikasi Organisasi}

Komunikasi organisasi dapat didefinisikan sebagai penampilan atau penafsiran yang dilakukan oleh unit organisasi yang merupakan bagian suatu organisasi. Definisi ini dilihat dari aspek fungsionalis sedangkan komunikasi interpretatif (subjektif) merupakanproses pembuatan makna atas interaksi pada organisasi. Komunikasi organisasi ialah " perilaku organisasi” yang mana didalamnya berjalan atau terjadinya proses yang mereka terlibat didalamnya. Adanya manusia sebagai "mereka" menjadi pelaku pada penaggapa pesan-pesan yang diterima dan disampaikan. Komunikasi organisasi dalam pandangan "objektif" menekankan pada "Struktur" sedangkan pandangan "subjektif" menekankan pada "proses" (waine, $2013: 33$ ).

\section{Teori Komunikasi Organisasi}

Terdapat berbagai macam teori komunikasi, salahsatunya teori komunikasi organisasi yang menjelaskan bagaimana seseorang yang memasuki lingkungan organisasi (pendatang baru) yang mencoba untuk membaur dengan lingkungan dan anggota organisasi tersebut. Teori ini disebut dengan Assimilation/sosialization theory yang ditemukan oleh Fred Jablin pada tahun 1982 (Pawit, 2009 : 169). Tahap pertama, Antisipatory Socialization Tahap kedua, The Counter Stage, Tahap ketiga, metamorphosis.

\section{HASIL DAN PEMBAHASAN}




\section{Konsep kajian dakwah Hizbiyah di Pimpinan Cabang Pemudi Persatuan Islam}

Model dakwah pada dasarnya pola atau acuan yang didalamnya sudah terbentuk proses penyampaian pesan dakwah. Jika dilihat dari jenis-jenis model dakwah terdapat tiga model dakwah; yaitu dakwah kultural, dakwah politik dan dakwah ekonomi. Kemudian jika dilihat dari model dakwah ada enam model yang meliputi; dakwah fardiyah, dakwah nafsiyah, dakwah fi'ah qolillah, dakwah hirbiyah, dakwah ummah dan dakwah syu'ubiyah qabaliyah.

Setiap madzhab yang ada di Indonesia termasuk kedalam model dakwah hizbiyah seperti, NU Muhamadiyyah, Persis dan yang lainnya. Pimpinan Cabang Pemudi Persatuan Islam margaasih menginduk kepada Persis sebagai panutan dalam berdakwah. Dari segi pendekatan dalam penelitian ini peneliti melakukan observasi mengenai kegiatan dakwah di pimpinan cabang pemudi persatuan islam margaasih, serta mewawancarai pihak yang menurut peneliti dapat menemukan hasil data yang akurat. Mengenai model dakwah di pemudi margaasih sebagaimana hasil wawancara peneliti kepada Ketua Pemudi Cabang Margaasih yaitu Teh Siti Khodijah berpendapat bahwa dakwah di pemudi biasanya berbentuk ceramah dan kajian-kajian khusus mengkaji kitab fikih. Berdasarkan hasil wawancara pada tanggal 26 Juni 2018 pukul 14.10 WIB di Rumah Siti Khadijah di Jalan Mahmud Kampung Kiaracondong Desa Rahayu Kecamatan Margaasih.

"Semenjak masuk keanggotaan pemudi pada periode Ibu Itoh tahun 2004, setahu saya betuk dakwah di Pemudi Persatuan Islam Cabang Margaasih memang dari dulu sampai sekarang bersifat ceramah umum, kajian-kajian khusus seperti Bulughul Maram. Pada kajian Bulughul Maram, dari periode Ibu Itoh sampai saya menjadi ketua sudah ada Karena kajian Bulughul Maram adalah suatu program dakwah lanjutan periode kepemimpinan sebelumnya.

Kemudian dalam wawancara selanjutnya peneliti mewanwancarai bidang garapan kegiatan dakwah yaitu Teh Yanti dan Teh Rifda, ada tanggal 27 Juni 2018 pukul 13.05 WIB di kantor Pemudi Persis Cabang Margaasih.

"Di pemudi itu sendiri dakwah dalam menyampaikannya melalui ceramah umum seperti pengajian biasa dan kajian khusus seperti Bulughul Maram dan tahdibuk akhlaq dan kehiatan tematik yang setiap bidang garapan memiliki program sesuai dengan bidang garapan tersebut. Pada jumat kesatu biasa diisi dengan ceramah umum dengan mubalighah dari Pimpinan daerah selaku pimpinan yang lebih tinggi. Kemudian pada jumat kedua diisi dengan kajian khusus yaitu kitab Bulughul Maram denga mubaigh Al-Ustadz Dudung sekalu mubaligh yang telah terjadwal. Pada jumat ketiga kegiatan dakwah sama diisi dengan kajian khusus yaitu 
mengeni tahdzibul akhlaq dengan pemateri al-Ustadzah Sumi selaku mubalighah yang telah terjadwal kemudian pada jumat keempat diisi denga kegiatan tematik, yaitu mengusung satu tema sesuai bidang garapannya masing-masing seperti seminar-seminar. Contohnya jika bidang garapan ekonomi mengisi pembahasan dengan tema perekonimian. Berdasarkan hasil musyawarah cabang periode sebelumnya yang lebih ditekankan materi atau tema yang disampaikan mengenai akhlaqul karimah, baik itu dari ceramah umum, kajian maupun tematik sesuai tema pendukung. Sebagaimana Pimpinan Pusat lebih menekankan kepada tema akhlaqul karimah. Terbilang sudah dua tahun yang sebelumnya mengusung tentang loyalitas dan tanggung jawab kejam'iyyahan. Kenapa di usung tema mengenai akhlqul karimah? Karena banyak kasus sebagian anggota pemudi yang berperilaku tidak sesuai dengan al-Qur'an dan As-Sunnah. Maka dari Pimpinan Pusat sendiri telah menetapkan bahwa yang lebi ditekankannya mengenai akhlaq".

Dalam proses dakwah Pemudi Persatuan Islam para mubaligh menyampaikan pesan dakwah kepada mad'u mempersiapakan penyampaian yang dapat direspon dengan baik. Model dakwah menjadi alat dan ciri khas tersendiri ketika dalam menyampaikan. Berdasarkan hasil wawancara kepada Ketua umum Pimpinan Pusat Pemudi Persatuan Islam pada tanggal 27 Juni 2018 yaitu Ibu Hj. Gyan Puspa Lestari pukul 08.45 di Rumahnya di Jalan Mahmud Kampung Curug 005/008 Desa Rahayu Kecematan Margaasih.

"Pada umumnya, dakwah dikalangan persatuan Islam menggunakan dakwah yang berbentuk bil-Lisan yaitu ceramah umum, pengajianpengajian, kajian-kajian khusus serta diskusi dan dialog. Dakwah dalam billisan mampu menarik perhatian masyarakat ketika mengadakan pengajian umum tetapi banyak juga kekurangan dari bentuk ceramah umum, yakni kurang kondusifnya suasana sehingga pesan dakwah yang disampaikan tidak tertangkap dengan sempurna. Oleh karena itu sarana dan pra sarana harus mendukung agar meminimalisir kekurangan bentuk dakwah bil-lisan. Pesan dakwah yang diterima oleh mad'u tergantung cara pembawaan da'i dalam menyampaikan pesan dakwah tersebut. Pemudi persatuan islam merupakan organisasi kaderisasi yakni mengkader anggota pemudi untuk dibina diarahkan sehingga dapat berkembangnya penerus ogranisasi pemudi ini. Tanpa ada pengkaderan untuk anggota pemudi hilangnya semangat jihad dan terlalainya rencana jihad untuk kedepannya.

\section{Materi Dakwah di Pimpinan Cabang Pemudi Persatuan Islam}


Hasil penelitian mengenai materi-materi dakwah yang digunakan oleh Pimpinan cabang pemudi persatuan Islam margaasih pada umumya berhubungan dengan aqidah, syariah dan akhlaq sebaimana yang bersumber dari Al-Qur'an dan AsSunnah. Dari beberapa materi yang disampaikan untuk berdakwah dipengajian biasanya lebih menekankan kepada akhlaq, meski begitu materi yang terkandung dari aqidah dan syariah juga pentingnya.

Materi dakwah yang disampaikan oleh da'i juga harus sesuai dengan objek dakwah itu sendiri, harus menyesuaikan dengan tema, waktu dan kondisi. Jangan sampai terjadi ketidakseimbangan antara pesann dakwah yang didampaikan dengan kondisi mad'u. pedan dakwah berisi tentang keislaman, kejamiyyahan sehingga tercapainya tujuan yang telah ditentukan. Pada hasil Wawancara: Siti Khodijah pada tanggal 26 Juni 2018 pukul 14.10 WIB

"Pada periode kedua sesudah musyker kemarin, pemudi margaasih menekankan kepada kegiatan dakwah kepada akhlaq pada umumnya. Karena banyak pemudi yang kurang berakhlaq baik dari perilaku, penampilan yang sesuai dengan al-Qur'an dan As-Sunnah. Secara keseluruhan dakwah di pemudi persis margaasih bentuk dakwahnya ceramah umum, kajian-kajian khusus dan tematik sesuai tema yang diusung disetiap bidang garapannya".

Ada beberapa kegiatan dakwah meliputi jenis kegiatan ceramah umum, kahian khusus maupun tematik yang bersumber dari Al-Qur'an dan As-Sunnah diantaranya. Ceramah umum, kegiatan dakwah di pimpinan cabang pemudi persatuan islam lebih bersifat mengadakan pengajian-pengajian, ceramah umum yang bertujuan memberikan nasehat, ilmu mengenai keislaman kepada anggota pemudi. Para da'i di undang untuk mengisi pengajian kepada pemudi dengan tema yang tidak ditentukan, otomatis da'i itu sendiri yang menentukan.

Kegiatan selanjunya ialah kajian khusus. kajian-kajian khusus diterapkan di Pimpinan cabang pemudi persatuan Islam Margaasih dengan bertemakan khusus menggunakan kitab-Fikih seperti Bulughul Maram dan Tabdibul akblaq. Kajian khusus ini lebih menekankan bersumber dari Al-hadist untuk menuntut anggota pemudi agar mengikuti sunah-sunah Rasul. Kajian Khusus dengan menggunakan kitab fikih yaitu kitab Bulugbul Maram sebagai pedoman menyunahkan kebiasaan Nabi Muhammad, adab-adab mulai dari pembahsan mengenai Thoharah sampai pembahasan mengenai muamalah. Kemudian kajian khusus bertema tabdibul akblaq membahas mengenai adab dalam berprilaku yang baik dan mengetahui perilaku makan yang buruk. Baik itu akhlaq diri sendiri, akhlaq kepada orang lain dan yang lainnya.

Dan yang terakhir ialah kegiatan tematik, tematik merupakan salah satu kegiatan dakwah di Pimpinan Cabang Pemudi Persatuan Islam Margaasih dengan pembahasan yang bertema. Setiap bidang garapan harus mempunyai satu kegiatan tematik yang sesuai dengan program kerja agar setiap bidang mampu 
mempertanggung jawabkan dalam bidangnya. Tematik ini diusung pertama kali menjadi sebuah program karena pembaruan dari pengajian-pengajian sebelumnya yang mana kegiatan hanya berbentuk ceramah umum agar angggota pemudi lebih mengentahui kelimuan yang lain.

Pada kegiatan dakwah di Pimpinan cabang Pemudi Persatuan Islam ada beberapa kegiatan perbidang diantaranya, Bidang Garapan Kaderisari : Mengadakan pengarahan kejam'iyaah di Pimpinan Cabang dan Pimpinan Jamaah kepada anggota maupun simpatisan agar setiap anggota pemudi atau simpatisan menjadi kader-kader pemudi yang intelek dan berjiwa kepemimpinan. Dan tidak hanya pengarahan kejamiyyahan saja.

Bidang Garapan Kaderisasi yaitu Kaderisasi, bertanggung jawab atas pembinaan dan pengembangan potensi anggota dicabangnya, menginventarisasikan potensi yang dimiliki anggota di cabang dan mengoptimalkan pendayagunaannya dan mengkoordinasikan dan mengupayakan penanganan pembinaan anggota dan penanganan pembinaan anggota dan kuantitas anggota. Mengadakan pengarahan kejam'iyaah di Pimpinan Cabang dan Pimpinan Jamaah kepada anggota maupun simpatisan agar setiap anggota pemudi atau simppatisan menjadi kader-kader pemudi yang intelek dan berjiwa kepemimpinan. Dan tidak hanya pengarahan kejamiyyahan saja.

Bidang Garapan Organisasi, pada periode kemarin bidang garapan organisasi megadakan kegiatan sosialisasi kejamiyyahan. Bagaimana jam'iyyah itu di bangun dengan dasar gotong royong dan berjamiyyah. Kemudian bidang garapan organisasi juga mengadakan tematik dari tema Tematik "Kenapa Di Indonesia Harus Ada Ormas Islam?”.

Bidang garapan pendidikan yaitu mengkoordinasikan serta mengawasi dan membina pengembangan jama'ah, mengkoordinasikan pendayagunaan potensi jamiyah dan kemampuan manajerial pimpinan jamiyyah di daerah kerjanya. Kegiatan dakwah di bidang garapan pendidikan tentunya mengadakan suatu kegiatan tematik perbidang garapannya. Pada bidang garapan pendidikan mengadakan kegiatan tematik dengan tema "Menangkal Mitos seputar Asi". Kegiatan ini pada periode tahun kemarin.

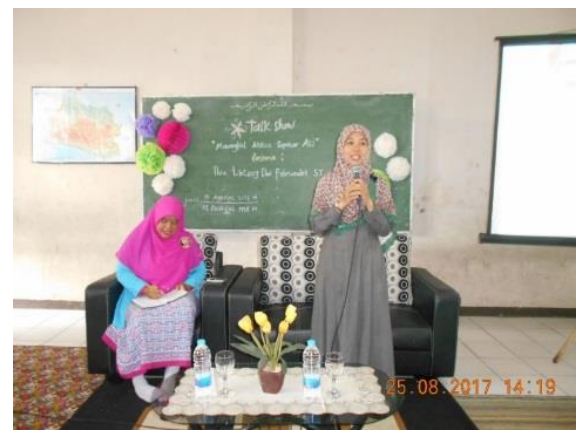

Sumber Gambar : Koleksi pribadi 
Gambar 1 : Kegiatan dakwah garapan bidang pendidikan

Bidang garapan dakwah yaitu menjadi koordinator kegiatan yang berhubungan dengan kegiatan dakwah di pimpinan cabang. Kemudian menyelengarakan pengajian-pengajian untuk pendalaman, pemahaman, dan pengamalan Al-Qur'an dan As-Sunnah bagi anggota dan calon anggota serta mengadakan kerja sama dengan lembaga-lembaga dakwah di daerah kerjanya.

Inti dari kegiatan dakwah yaitu semua aspek termasuk pada kegaitan dakwah, seperti kegiatan rutinan, kajian dan yang lainnya. Tetapi dakwah juga mempunya kegiatan tematik yang mewajibkan perbidang garapan mempunyai satu kegiatan. Pada periode tahun kemarin Bidang garapan dakwah mengadakan cukup banyak kegiatan tematik dengan bertemakan "Hikmah Mukjizat AlQur'an", "Multi Peran Perempuan menurut al-Quran \& as-Sunnah", Bedah Buku" Merangkai Kata Menjadi Karya". Dan pada periode tahun kedua ini bidang garapan dakwah telah mengadakan kegiatan tematik dengan tema "Meneladani Ghiroh Jihad Ummul Mukminin Khadijah".

Bidang Garapan Seni dan Budaya yaitu memimipin bidagar seni dan budaya serta, bertanggung jawab atas pelaksanaan berbaga aktivitas yang berkaitan dengan pengembangan seni dan budaya sebagai media dakwah. Kemudia membantu ketua bidang garapan pendidikan melaksanakan tugas jamiyyah dalam bidang seni dan budaya, menyampaikan pemikiran atau gagasan strategis di bidang seni dan budaya sebagai media dakwah serta menuangkannya secara sistematis untuk disampaikan kepada keua idang penididkan. Kemudian mengkoordinasikan upaya pengembangan wawasan seni islami

Kegiatan seni dan budaya merupakan kegiatan tambahan dan juga bidang garapan tambahan pada periode tahun-tahun sebelumnya karena seni dan budaya perlu juga dilahirkan karena anggota pemudi perlu juga memiliki penguasahaan kreatifitas sehingga tidak bosan monoton terus menerus diberikan materi ceramah umum. Kegiatan seni dan budaya dilaksanakan pada dua bulan sekali. Kegiatan seni dan budaya ini tidak menghilangkan seni keislamiannya. Bidang garapan seni dan budaya mengadakan kegiatan pada periode tahun kemarin yaitu tematik dengan tema "Tuntunan Berhias Yang Sesuai Dengan Syari'at Islam Plus Tutorial Make Up Syar'I”, “KeterampilanMembuat Keranjang Gelas Dari Bekas Minuman Kemasan”, "Keterampilan "Membuat Gantungan kunci Dari Bekas Kemasan Kopi” serta Sosialisasi Shurul Khan Pemudi. 


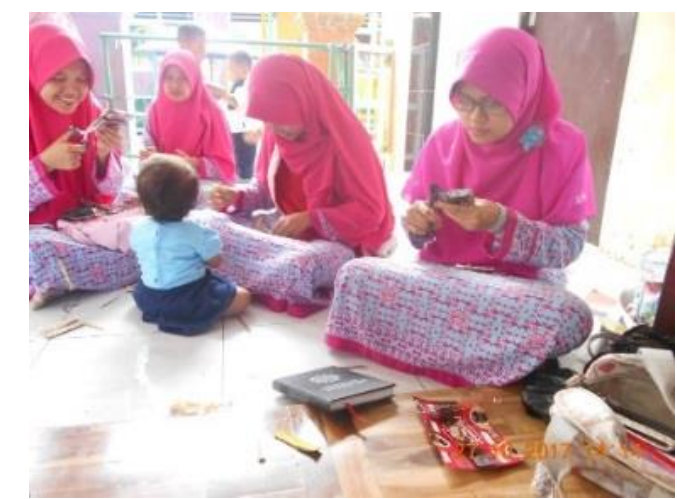

Sumber Gambar : Koleksi pribadi

Gamar 2 : kegiatan dakwah bidang garapan seni dan budaya

Sumber gambar : koleksi pibadi

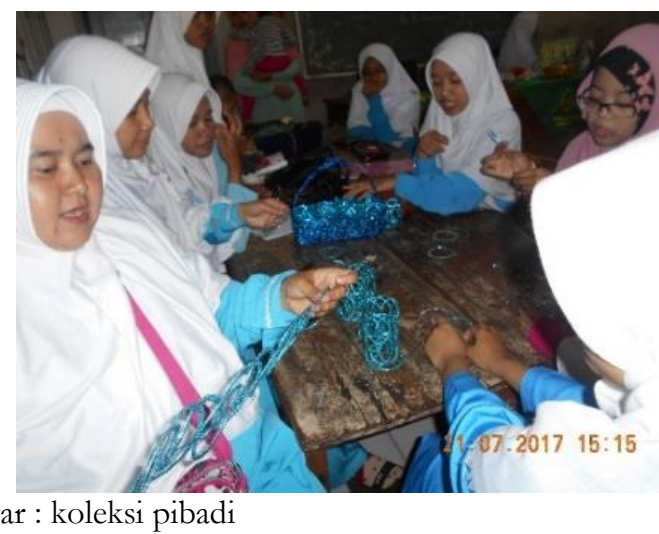

Gambar 3 : kegiatan dakwah bidang garapan seni dan budaya

Bidang garapan Pengambidan pada masyarakat (PPM) yaitu mengkoordinasikan dan menggalakan pengabdian pada masyarakat demi kemashlahatan dan kesejahteraan anggota, jama'ah, dan umat Islam secara umum. Tidak hanya mengabdi, membantu kepada masyarakat bidang garapan ini juga mempunyai kinerja pada kegiatan tematik pada bidang garapan PPM juga mempunyai kegiatan wajib setiap bidang garapannya yaitu mengadakan kegiatan tematik dengan tema "Pemudi Sadar Sosial".

Bidang Garapan Ekonomi yaitu mengupayakan peningkatan, kesejahteraan taraf hidup anggota, jama'ah dan umat yang ekonominya masih lemah. Pada periode tahun pertama bidang garapan ekonomi mengadakan kegiatan sesuai dengan bidang garapannya yaitu kegiatan tematik dengan tema "Meningkatkan Ekonomi Jam’iyyah Melalui Fundrising”.

Bidang Garapan Informasi dan Komunikasi yaitu memimpin bidang garapan informasi dan komunikasi serta bertanggung jawab atas pelaksanaan berbagai aktivitas yang berkaitan dengan kelancaran informasi dan komunikasi serta merancang strategi pengembangan jaringan informasi yang tercakup secara 
bottom up dan top down sehingga anggota mauapun simpastisan dapat memperoleh akses informasi yang berkaitan dengan perkemangan jamiyyah.

Bidang garapan infokom tidak hanya untuk menginfomasikan segala jenis kegiatan, jadwal kegiatan dan yang lainnya. Bidang garapan ini juga mengadakan kegiatan tematik sesuai dnegan bidang garapannya dengan bertemakan Tematik "Bijak Menggunakan Medsos".

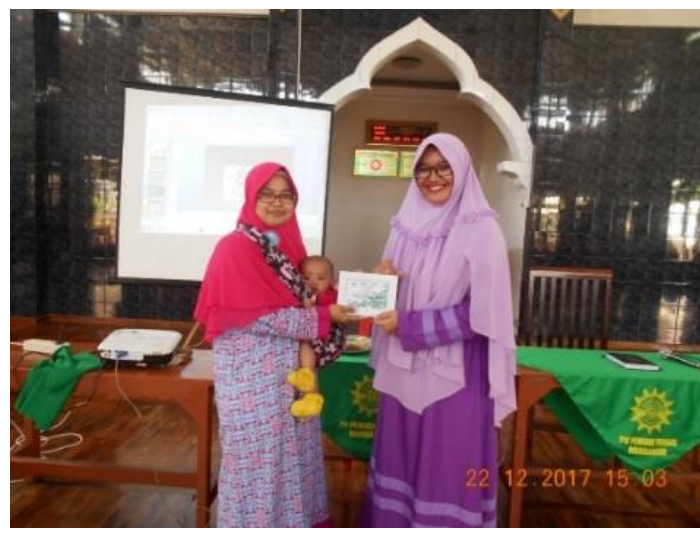

Sumbe gambar : koleksi pribadi

Gambar 4 : kegiatan dakwah bidang garapan infomasi dan komunikasi

Bidang Garapan Hubungan Antar Lembaga yaitu mengkoordinasikan upaya pengembangan wawasan yang berkaitan dengan hubungan antar lembaga untuk membuat dan membuka akses yang luas lagi dengan berbagai kalangan sehingga terbangun net work yang baik. kegiatan pada bidang garapan ini merupakan kegiatan umum, yang diikuti oleh berbagai kalangan. Tidak hanya anggota pemudi dan simpatisan cabang margaasih saja, tetapi lebih ke masyarakat untuk ikut berpartisipasi walaupun itu bukan anggota pemudi. Bidang garapan Hubungan antar Lembaga biasa disebut HAL juga memiliki kegiatan tematik sesuai dengan bidang garapannya. Kegiatan tematik HAL lebih berhubungan dengan membantu masyarakat seperti kesehatan keliling bekerja sama dengan Pusat Zakat Umat cabang Margaasih sebagai donatur. 


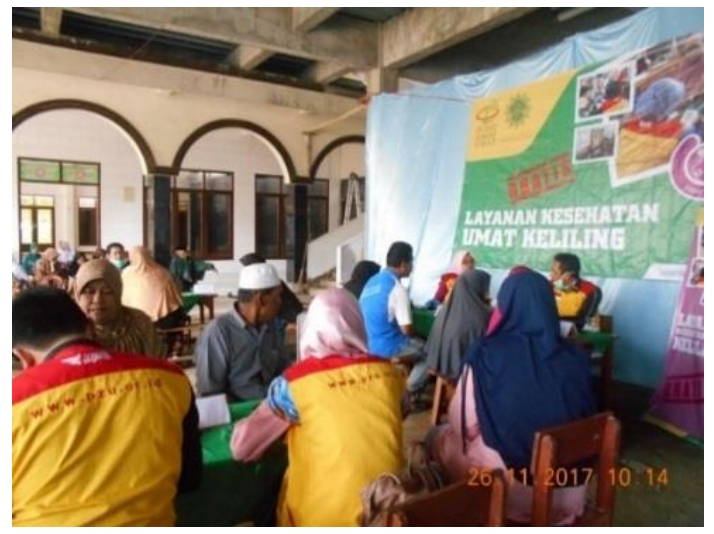

Sumber gambar : koleksi pribadi

Gambar 5 : Kegiatan dakwah bidang garapan hubungan antar lembaga

\section{Metode dakwah di Pimpinan Cabang Pemudi Persatuan Islam Margaasih}

Umat Islam pada dasarnya adalah umat dakwah, setiap muslim berkewajiban untuk melaksanakan amar ma'ruf dan nahyi munkar sesuai dengan kapasitasnya. Umat Islam diposisikan oleh Allah sebagai umat yang terbaik kemudian diturunkan di tengah masyarakat di dunia. Dalam perkembangan zaman, proses berdakwah memiliki kualitas dan kuantitas untuk hail yang baik.

Pada dasarnya pula metode dakwah merupakan cara untuk penyampaian pesan dakwah kepada mad'u dintaranya ada motode dakwah bil hikmah, mauidzah hasanah dan mujadalah. Ketiga metode dakwah tersebut telah ditetapkan dalam Al-Qur'an. Pada sebuah pengajian atau ceramah umum biasanya seorang da'i mengggunakan cara dalam menyampaikan pesan dakwah dengan metode yang bermacam-macam.

Pada sebuah pengajian atau ceramah umum biasanya seorang da’i mengggunakan cara dalam menyampaikan pesan dakwah dengan metode yang bermacam-macam. Di Pimpinan cabang Pemudi Persatuan Islam Margaasih itu sendiri menggunakan metode dakwah bil hikmah yaitu metode dengan keilmuan dan wawasan pengetahuan yang luas gar anggota pemudi dapat menyerap pesan dakwah dengan baik dan bisa mengamalkannya. Berkaitan dengan metode dakwah bil hikmah, metode dakwah mauizah hasanah juga termasuk dalam cara penyampaian di pemudi yaitu dengan melihat situasi dan kondisi mad'u, tutur kata yang baik, nasihat yang baik pula serta dapat dirasakan dan diresap oleh anggota pemudi sebagai suatu bimbingan, ajakan dan pengarahan yang penuh perhitungan, bukan menjadi sebuah paksaan dan ancaman.

Dalam menyampaikan pesan dakwah atau materi dakwah Pemudi sendiri juga menggunakan metode dengan dakwah bil lisan, dakwah bil hal dan dakwah 
bil mal. Dakwah bil lisan yaitu dengan ceramah umum atau pengajian itu bertata muka langsung dengan mad'unya. Kemudian dengan dakawah bil hal yaitu pemudi berdakwah dengan perbuatan dalam membina, membantu, menolong dengan materi ataupun non materi kepada anggota pemudi yang kurang dalam segi ekonomi maupun ilmu. Dan yang terakhir dakwah bil mal, dakwah ini disebut dakwah karena cara menyampaikan dengan barang hal yang dimiliki bisa dianggap infaq atau shodaqah.

Di Pimpinan cabang Pemudi Persatuan Islam Margaasih itu sendiri menggunakan metode dakwah bil hikmah yaitu metode dengan keilmuan dan wawasan pengetahuan yang luas gar anggota pemudi dapat menyerap pesan dakwah dengan baik dan bisa mengamalkannya. Berkaitan dengan metode dakwah bil hikmah, metode dakwah mauizah hasanah juga termasuk dalam cara penyampaian di pemudi yaitu dengan melihat situasi dan kondisi mad'u, tutur kata yang baik, nasihat yang baik pula serta dapat dirasakan dan diresap oleh anggota pemudi sebagai suatu bimbingan, ajakan dan pengarahan yang penuh perhitungan, bukan menjadi sebuah paksaan dan ancaman.

Dalam menyampaikan pesan dakwah atau materi dakwah Pemudi sendiri juga menggunakan metode dengan dakwah bil lisan, dakwah bil hal dan dakwah bil mal. Dakwah bil lisan yaitu dengan ceramah umum atau pengajian itu bertata muka langsung dengan mad'unya. Kemudian dengan dakawah bil hal yaitu pemudi berdakwah dengan perbuatan dalam membina, membantu, menolong dengan materi ataupun non materi kepada anggota pemudi yang kurang dalam segi ekonomi maupun ilmu. Dan yang terakhir dakwah bil mal, dakwah ini disebut dakwah karena cara menyampaikan dengan barang hal yang dimiliki bisa dianggap infaq atau shodaqah.

Hasil penelitian mengenai metode dakwah yang digunakan dalam menyempaikan pesan dakwah oleh Pimpinan cabang Pemudi Persatuan Islam Margaasih meliputi pendekatan bentuk bil-hikmah yaitu metode yang lebih menekankan wawasan keilmuan dengan cara penyampaian yang tegas dan lugas agar mad'u yaitu anggota pemudi bisa menerima pesan dakwah dengan baik. Metode ini biasa digunakan pada umumnya untuk merangkul anggota pemudi tidak ada unsur pemaksaan. Kemudian metode dakwah selanjutkan yang digunakan di Pimpinan Cabang Pemudi Persatuan Islam Margaasih yakni mauidzah hasanah karena diketahu bahwa metode ini memiliki sifat atau cara penyampaiannya dengan teratur serta perkataan yang lemah lembut. Sebagaimana wawancara kepada Bidang Garapan Dakwah.

"Kegiatan dakwah di pemudi itu tidak hanya berbentuk pengajian atau ceramah umum saja tetapi mengadakan suatu sosialisasi bantuan kepada sesama yang sedang membutuhkan. Seperti menyumbang kepada anggota pemudi yang sedang terjadi musibah banjir, kebakaran dan longsor dan yang lainnya. Dengan cara memberikan sedikit sumbangan uang dan 
sembako dengan cara mengumpulkan uang dari anggota pemudi lain dengan dikatann itu sodaqah atau sumbangan. Selain itu, di pimpinan cabang atau jamaah biasnaya ketika ada anggota pemudi yang sedang sakit atau melahirkan biasnaya suka menengok dengan glangan dana sumbangan dari anggota pemudi lain. Jadi sistem keuangan di Pemudi adalah dari pemudi untuk pemudi kurang lebih seperti itu. Kemudian kegiatanbil-hal tahuanan serta gabungan bersama persistri yaitu membagikan takjil kepada masyarakat sekitar margaasih kurang lebih 100 takjil dibagian pada kegiatan ini. Dengan teknik dakwah lain yaitu dakwah bil qolam. Di pimpinan Cabang Pemudi Persatuan Islam dakwah melalui bil qalam diantaranya membuat dakwah blog di aktiker media internet kegiatan dakwah di facebook dan instagram. Dan dakwah melalui mading (majalah dinding)".

Dalam penyampaian model dakwah yang digunakan di Pimpinan cabang pemudi persatuan Islam yaitu diantaranya, Mauidzatil Hasanah (nasihat yang baik) Salah satu metode yang terdapat didalam ayat Al-Qur'an yaitu berdakwah dengan menggunakan nasihat yang baik. Pada pelaksanaan dakwah di Pimpinan Cabang Pemudi Persatua Islam Margaasih menggunakan metode manidzatil hasanah. Metode ini dilakukan atau digunakan oleh da'i kepada mad'u ketika berdakwah melalui dialog pada saat ceramah berlangsung ataupun setelah ceramah selasai.

Metode ini dilakukan secara berdialog oleh da'i kepada mad'u untuk memperjelas atau meminta problem solving terhadap apa yang mad'u hadapi. Seperti dalam kegiatan dakwah pemudi yaitu Halaqah . untuk itu, pada kegiatan dakwah halaqah biasanya bertatap muka dalam menyalurkan pesan dakwah (nasehat).

Mujadalah (berdebat dengan baik) Metode ini biasa digunakan oleh pimpinan cabang pemudi persatuan islam margaasih kepada para simpatisan atau anggota yang baru dan keilmuannya yang tinggi dengan mayoritas lebih ingin mengetahui secara mendalam mengenai ajaran Persatuan Islam. Dan kebanyakan orang-orang yang berdialog pada ajaran diterapkan oleh persatuan Islam belum terlalu banyak orang yang mengetahui. Bahkan sering dianggap ajaran yang berbeda.Sebagaimana wawancara kepada Bidang Garapan Dakwah ;

"Kegiatan dakwah di pemudi itu tidak hanya berbentuk pengajian atau ceramah umum saja tetapi mengadakan suatu sosialisasi bantuan kepada sesama yang sedang membutuhkan. Seperti menyumbang kepada anggota pemudi yang sedang terjadi musibah banjir, kebakaran dan longsor dan yang lainnya. Dengan cara memberikan sedikit sumbangan uang dan sembako dengan cara mengumpulkan uang dari anggota pemudi lain dengan dikatann itu sodaqah atau sumbangan. Selain itu, di pimpinan cabang atau jamaah biasnaya ketika ada anggota pemudi yang sedang sakit 
atau melahirkan biasnaya suka menengok dengan glangan dana sumbangan dari anggota pemudi lain. Jadi sistem keuangan di Pemudi adalah dari pemudi untuk pemudi kurang lebih seperti itu.

Kemudian pada Hasil Penelitian Dakwah Hizbiyah Dalam Kegiatan Dakwah Di Pimpinan Cabang Pemudi Persatuan Islam Margaasih model dakwah pimpinan cabang pemudi persatuan islam margaasih ini tergolong mudah-mudah susah karena tantangan dakwah di zaman sekarang sanga tlah memeperlukan strategi yang kuat agar tercapainya ajaran yang sesuai dengan Al-qur'an dan AsSunnah. Walaupun pada hasil wawancara atau pada faktanya memang masih sangat kurang, akan tetapi ajaran dakwah di Pimpinan Cabang Pemudi Persatuan Islam Margaasih sangat berdampak positif kepada mad'u dalam menanamkan ghiroh keilmuan.

\section{PENUTUP}

\section{Simpulan dan Saran}

Dari hasil penelitian yang telah dilakukan mengenai model dakwah hizbiyah menghasilkan sebagai berikut, Konsep kajian Dakwah dalam penelitian ini adalah adanya proses dakwah yang para mubaligh menyampaikan pesan dakwah kepada mad'u mempersiapakan penyampaian yang dapat direspon dengan baik. Model dakwah menjadi alat dan ciri khas tersendiri ketika dalam menyampaikan. Didalam konsep kajian dakwah memnanmlan keilmuan yang berlandaskan dengan Al-Qur'an dan As-Sunnah.

Materi dakwah di Pimpinan Cabang Pemudi Persatuan Islam pada intinya bersumber dari Al-Qur'an dan As-Sunnah. Materi aqidah, syariah dan akhlaq, dan secara khusus penekanan materi akhlaq lebih diutamakan sesuai dengan visi dari Pemudi Persatuan Islam yakni mewujudkan anggotanya Bunyanul Islam yang diisi oleh al-Mar'atus Sholohah dan Pemudi Persatuan Islam Cabang Margaasih sebagai wadah untuk mencetak generasi yang berakhlaqul karimah merangkul untuk mengembalikan akhlaq kepada Al-Qur'an dan As-Sunnah.

Metode dakwah yang digunakan pada Pimpinan Cabang Pemudi Persatuan Islam Margaasih yakni metode dakwah bil-hikmah, metode bil-hikmah lebih menekankan kepada keilmuan dan pengembangan wawasan. Metode dakwah mauizah hasanah juga termasuk dalam cara penyampaian di Pimpinan Cabang Pemudi Persatuan Islam Margaasih, dengan melihat situasi dan kondisi mad'u, tutur kata yang baik, nasihat yang baik pula serta dapat dirasakan dan diresap oleh anggota pemudi sebagai suatu bimbingan, ajakan dan pengarahan yang penuh perhitungan, bukan menjadi sebuah paksaan dan ancaman.

Sedangkan saran untuk objek penelitian yang dilakukan Berkenaan dengan kegiatan dakwah di Pimpinan Cabang Pemudi Persatuan Islam Margaasih, Pertama, bisa melahirkan kembali kegiatan dakwah yang lebih menarik anggota 
Ismawati, Syamsuddin SR \& Nase

pemudi dalam mengikuti kegiatan dakwah, tidak hanya ceramah umum saja akan teapi membuat ketertarikan dalam menyampaikan pesan dakwah. Kemudian lebih di matangkan ketika mmebuat kegiatan dakwah bersifat tematik. Mengusung tema yang sesuai dengan wawasan oleh anggota pemudi.

Kemudian saran untuk akademisi dakwah Pada penelitian ini dirasakan belum sempurnn masih terdapat kekurangan baik itu dari hasil data dan analisis data. Namun demikian sekiranya skripsi ini bisa menjadi salah satu bahan atau acuan untuk penelitian selanjutnya yang berhubungan dengan model dakwah hizbyah. Sedangkan untuk praktisi sendiri Ada beberapa model yang berkembang di dunia dakwah Islam di berbagai tempat, salah satu model dakwah yang dikembangkan oleh praktisi sebagaimana yang telah saya dapatkan dari penelitian ini sekiranya hasil penelitian ini bisa dijadikan model dakwah untuk para da'i dalam berdakwah.

\section{DAFTAR PUSTAKA}

Al-bayanuni. (2001). al-Madkhal ila "ilmi al-Da'wah. Resalah Publishers.

As. E. A. (2009). Dasar-Dasar Ilmu Dakwah. Bandung: Widya Padjajaran.

Basith, A. (2013). Filsafat Dakwah. Jakarta.

Departemen Agama RI. (2004). Al-qur'an dan terjemah Al-jumanatul 'Ali. Bandung: CV Penerbit Jumanatul 'Ali-Art.

Enjang, A. (2009). Dasar Dasar Imu Dakwah. Bandung: Widya Padjajaran

Muhammad, P. (2013). Ilmu Informasi, Komunikasi dan Kepustakaan, Jakarta.

Saepuloh, Ujang. (2009). Model Komunikasi Dakwah Jamaah Tabligh dalam Ilmu Dakwah : Academic Journal for Homiletic Studies Jurnal Ilmu Dakwah, Vol. 4 No. 14 Juli-Desember 2009. 682

Bandung: Simbiosa Rekatama Media.

Suhandang, D. K. (2013). Ilmu Dakwah Perspektif Komunikasi. Bandung: PT Remaja osdakarya.

Solahudin, D. (2014). Dakwah Hiziyah dalam Konteks Pemilu 2005 dalam ilmu dakwah: Academic Journal for Homilities Studens, Vol. 2No. 3 Januari-Juni 2004. 